Jurnal Pemberdayaan: Publikasi Hasil Pengabdian kepada Masyarakat

Vol. 3, No. 2, Agustus 2019, Hal. 225-230

ISSN: 2580-2569; e-ISSN: 2656-0542

DOI: https://doi.org/10.12928/jp.v3i2.565

\title{
Workshop penyusunan karya ilmiah bagi guru-guru SMP Muhammadiyah se-Kabupaten Bantul
}

\author{
Widayati, Vita Istihapsari \\ Universitas Ahmad Dahlan, Jalan Ringroad Selatan, Tamanan, Bantul, Yogyakarta, Indonesia \\ Email: widayati@pmat.uad.ac.id
}

\begin{abstract}
ABSTRAK
Sejumlah guru SMP Muhammadiyah Bantul memiliki kesulitan dalam membuat karya ilmiah. Di sisi lain, karya ilmiah guru merupakan salah satu item dalam penilaian akreditasi sekolah di SMP Muhammadiyah Bantul, selain juga dapat dijadikan bahan kenaikan golongan para guru. Sehingga, dibutuhkan suatu pelatihan yang dapat membantu para guru dalam penyusunan karya ilmiah. Pelatihan dan workshop ini diikuti oleh 20 guru SMP Muhammadiyah Bantul. Adapun tujuan dari kegiatan ini adalah untuk memberi pembimbingan penyusunan pembuatan karya ilmiah kepada guru-guru SMP Muhammadiyah di Bantul. Kegiatan diawali dengan guru melakukan penelitian dalam pembelajaran. Selanjutnya dari hasil penelitian tersebut, guru menyusun karya ilmiah yang dapat dipublikasikan. Metode yang digunakan pada kegiatan ini adalah dengan mengadakan pendampingan kepada guru-guru matematika SMP Muhammadiyah di Bantul dalam pelatihan dan workshop pembuatan penelitian dan menyusun Karya Ilmiah. Hasil angket yang diberikan kepada guru, sebelum dan sesudah mengikuti workshop, diperoleh nilai rata-rata sebelum mengikuti workshop yaitu 33,28 pada kategori cukup, dan nilai ratarata sesudah mengikuti workshop yaitu 37,09 pada kategori baik. Hasil dari kegiatan ini adalah guru-guru SMP Muhammadiyah di Bantul dapat membuat karya ilmiah yang berkualitas sehingga dapat dijadikan bahan kenaikan golongan maupun penilaian pada akreditasi sekolah.
\end{abstract}

Kata kunci: karya ilmiah, workshop, PTK

\begin{abstract}
Several Muhammadiyah Bantul Middle School teachers have difficulties in doing scientific work. On the other hand, the teacher's scientific work is one of the items in the school accreditation assessment in the Muhammadiyah Bantul Middle School, besides it can also be used as material for teacher promotion. So, we need training that can help teachers in preparing scientific papers. The 20 Muhammadiyah Bantul Middle School teachers attended this training and workshop. The purpose of this activity is to guide the preparation of the making of scientific papers to Muhammadiyah Middle School teachers in Bantul. The event begins with the teacher researching learning. Furthermore, from the results of the research, the teacher compiles scientific papers that can be published. The method used in this activity is to provide mentoring to mathematics teachers of Muhammadiyah Middle School in Bantul in training and research doing workshops and compiling Scientific Work. The results of the questionnaire given to teachers, before and after attending the seminar, obtained an average value before attending the seminar which was 33.28 in the sufficient category, and the average score after attending the workshop was 37.09 in the good category. The result of this activity is that Muhammadiyah Middle School teachers in Bantul can produce quality scientific work so that it can be used as material for class promotion or assessment on school accreditation.
\end{abstract}

Keywords: scientific paper, workshop, PTK 


\section{PENDAHULUAN}

SMP Muhammadiyah Bantul, SMP Unggulan Aisyiah, dan SMP Muhammadiyah Sewon 1 terletak di Kabupaten Bantul DIY, yang telah menggunakan Kurikulum 2013. SMP Muhammadiyah Bantul terletak di Jalan Gajah Mada No. 7b Bantul, SMP Unggulan Aisyiyah Bantul terletak di Jalan Ir. H. Juanda No. 103 Trirenggo Bantul, sedangkan SMP Muhammadiyah 1 Sewon terletak di Bandung Kulon, Pendowoharjo, Sewon, Bantul. SMP Unggulan Aisyiyah, misalnya, memiliki keunikan yang jarang dimiliki oleh sekolah-sekolah lainnya. Keunikan tersebut berupa komitmen, karakter, dan budaya sekolah yang tertanam kuat pada semua warga sekolah terutama tercermin pada visi dan misi yang jelas. Berdasarkan hasil survei dan wawancara dengan pihak sekolah, pengusung mendapatkan informasi bahwa sekolah ini memiliki 27 guru, namun sedikit yang telah menghasilkan karya ilmiah.

Karya ilmiah adalah sebuah tulisan yang berisi suatu permasalahan yang diungkapkan dengan metode ilmiah (Brotowidjoyo, 1985). Karya ilmiah juga dapat disebut suatu karangan ilmu pengetahuan yang menyajikan fakta dan ditulis menurut metodologi penulisan yang baik dan benar (Arifin, 2003; Effendi, 1987). Sehingga, pengungkapan permasalahan dalam karya ilmiah itu harus berdasarkan fakta, bersifat objektif, tidak bersifat emosional dan personal, dan disusun secara sistematis dan logis.

Bahasa yang digunakan adalah bahasa Indonesia ragam baku dengan memperhatikan kaidah EYD dan pembentukan istilah. Sumardi (2011) menyatakan bahwa keprofesionalan guru yang sangat diharapkan dan wajib dimiliki oleh setiap guru yang sudah memiliki sertifikat pendidik dan sudah mendapatkan tunjangan sertifikasi guru/pendidik. Karya ilmiah merupakan suatu sarana kreativtas dan inovatif peningkatan tugas guru dalam pembelajaran di kelas.

Pada kenyataannya, guru belum terbiasa mengadakan penelitian dan membuat karya ilmiah. Sehingga, karya ilmiah dari guru sangat jarang didapatkan. Di sisi lain, guru sudah disibukkan dengan tugas lain yaitu membuat RPP dan lain sebagainya. Selain itu, kendalakendala yang dialami dalam pelaksanaan pembelajaran matematika perlu untuk dicarikan solusi. Salah satu upaya untuk memperbaiki dan mencari solusi dalam permasalahan pada pembelajaran adalah guru melakukan penelitian. Guru akan memperoleh hasil bagaimana upaya guru dalam memperbaiki atau meningkatkan proses pembelajaran dan hasil pembelajaran, melalui penelitian tersebut.

Setelah guru selesai melakukan penelitian, hasil dari penelitian tersebut dapat dijadikan sebagai karya ilmiah. Untuk itu para guru perlu mengetahui cara penulisan karya ilmiah, langkah-langkah yang harus dilakukan supaya hasil karya ilmiah baik dan benar.

Berdasarkan tingkat akademisnya, karya ilmiah dapat dibedakan atas lima macam, yaitu makalah, laporan penelitian, skripsi, tesis, dan disertasi. Makalah adalah karya tulis yang memerlukan studi, baik secara langsung maupun tidak langsung, dapat berupa kajian pustaka/buku, kajian suatu masalah, analisis fakta hasil obsevasi. Laporan penelitian merupakan sebuah tulisan yang dibuat setelah orang melakukan penelitian, pengamatan, wawancara, pem,bacaan buku, perccobaan, dan lain-lain. Adapun skripsi merupakan jenis karya ilmiah yang ditulis oleh mahasiswa strata satu (S1) untuk memperoleh gelar sarjana, tesis ditulis oleh mahasiswa strata dua (S2) untuk memperoleh gelar magister, dan disertasi ditulis oleh mahasiswa strata tiga (S3) untuk memperoleh gelar doktor. Namun, untuk keperluan pelatihan ini, difokuskan pada penulisan laporan penelitian.

Berdasarkan survey dan wawancara dengan pihak sekolah yaitu ibu Istianah selaku Kepala Sekolah di SMP Muhammadiyah Bantul mendapatkan informasi bahwa masih sedikit guru yang mempunyai karya ilmiah, untuk persiapan akreditasi sekolah yang masih sangat kurang dalam hal penulisan karya ilmiah para guru. Hasil ini mengungkap fakta bahwa para guru masih kesulitan dalam membuat karya ilmiah. Sehingga, Kepala Sekolah SMP Muhammadiyah Bantul meminta bantuan kepada kami selaku dosen UAD untuk dapat memberikan pelatihan pembuatan karya ilmiah. 
Berdasarkan permasalahan di atas, dalam upaya mengatasi kesulitan guru tersebut, maka selanjutnya diperlukan adanya pelatihan dan workshop pembuatan karya ilmiah, dengan dimulai melakukan penelitian, selanjutnya hasil penelitian disusun sebagai karya ilmiah yang dapat dipublikasikan. Hasil karya ilmiah ini, diharapkan bermanfaat bagi guru sendiri guna memperbaiki pembelajaran di kelas dan untuk menambah poin kenaikan pangkat, tetapi juga bermanfaat bagi sekolah secara umum guna mendukung dan menambah nilai dalam akreditasi sekolah.

\section{METODE}

Materi yang diberikan dalam kegiatan pengabdian ini adalah langkah-langkah dalam penelitian, cara menganalisis hasil penelitian, menyusun laporan hasil penelitian, membuat karya ilmiah dari hasil laporan penelitian, pedoman penulisan karya ilmiah, dan bagaimana cara membuat karya ilmiah yang baik dan benar. Metode yang digunakan adalah dengan mengadakan workshop dan pendampingan kepada guru-guru matematika SMP Muhammadiyah di Bantul. Untuk lebih detailnya, metode yang digunakan dalam kegiatan pengabdian kepada masyarakat ini, disajikan pada Gambar 1.

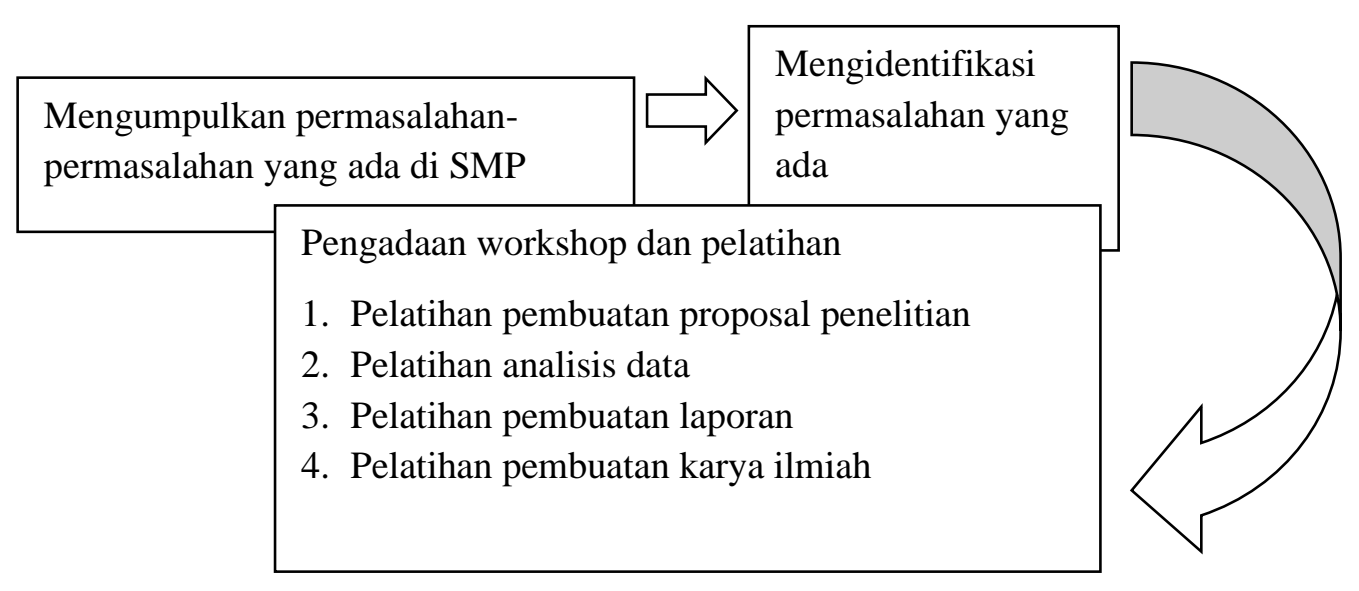

Gambar 1. Peta konsep kegiatan workshop dan pendampingan karya ilmiah

Guru melakukan penelitian dengan membuat proposal terlebih dahulu, selanjutnya melakukan penelitian di kelas. Jenis penelitian yang dilakukan guru adalah penelitian tindakan kelas. Dosen melakukan pendampingan selama proses penelitian dan penulisan karya ilmiah.

\section{HASIL, PEMBAHASAN, DAN DAMPAK}

Kegiatan pengabdian kepada masyarakat yang kami usung dimulai pada tanggal 23 Desember 2017 dengan melakukan koordinasi tim pengusung bersama mahasiswa yang membantu pelaksanaan kegiatan pengabdian. Selanjutnya, tim pengusung mengadakan rapat sebanyak dua kali dan menyiapkan bahan-bahan materi untuk acara workshop pada tanggal 30 Desember 2017. Pada tanggal 3 Januari 2018, kami mengadakan rapat koordinasi dengan PDM Muhammadiyah Bantul. Hasil rapat koordinasi tersebut adalah disepakati bahwa acara workshop bertempat di Gedung Dakwah PDM Bantul pada tanggal 8 Februari 2018.

Peserta kegiatan workshop terdiri dari perwakilan guru matematika SMP Muhammadiyah se-Kabupaten Bantul sebanyak 35 guru. Berdasarkan pengamatan tim, para guru terlibat aktif mengikuti workshop yang diselenggarakan pada hari Kamis tanggal 8 Februari 2018. Pemateri workshop tersebut berasal dari tim pengabdian sendiri, yaitu Dra. 
Widayati, M.Sc dan Vita Istihapsari, M.Pd, dosen Pendidikan Matematika FKIP Universitas Ahmad Dahlan Yogyakarta.

Sebelum workshop dimulai, kami memberikan kuesioner tentang karya ilmiah kepada peserta. Berdasarkan hasil kuesioner tersebut, kami mengetahui sejauh mana para guru memahami tentang pembuatan karya ilmiah. Dalam kuesioner tersebut, para guru juga mengisi harapan setelah mengikuti kegiatan workshop, di antaranya para guru berharap bisa memahami bagaimana menulis karya ilmiah yang baik serta termotivasi untuk membuat karya ilmiah. Selanjutnya pemateri memberikan bahan materi kepada para guru serta menjelaskan materi diikuti dengan diskusi. Para guru aktif mengikuti workshop, aktif berdiskusi. Guru-guru dipersilahkan untuk menulis pertanyaan ataupun permasalahan yang belum jelas tentang bagaimana menulis karya ilmiah. Adapun yang masih menjadi permasalahan dari peserta adalah bagaimana menentukan judul penelitian, bagaimana menuliskan masalah pada latar belakang masalah, bagaimana menuliskan kajian teori, bagaimana membuat kutipan, dan bagaimana melakukan penelitian tindakan kelas. Pada hari itu juga kami menjawab apa yang menjadi permasalahan guru-guru dalam menulis karya ilmiah. Sesi terakhir pada acara workshop adalah membuat proposal, diawali dengan membuat latar belakang masalah. Hasil angket yang diberikan guru, sebelum dan sesudah mengikuti workshop diketahui nilai rata-rata sebelum mengikuti workshop yaitu 33,28 pada kategori cukup serta nilai rata-rata sesudah mengikuti workshop yaitu 37,09 pada kategori baik.Workshop berjalan dengan lancar dari pukul 08.00 hingga 16.00 , peserta aktif berdiskusi, kemudian dilanjutkan perencanaan pembimbingan.

Pembimbingan kepada guru-guru yang akan membuat karya ilmiah dilakukan dengan cara membagi 20 sekolah ke dalam 3 kelompok, yang terdapat pada lampiran. Pembimbingan sudah berjalan pada semua kelompok. Pada saat ini hasil karya dari guru-guru belum selesai dikarenakan kesibukan mengajar dan kegiatan lain. Sebagian ada yang sudah selesai sampai Bab 3, yaitu pada kelompok 4, kemudian dilanjutkan pembahasan dan kesimpulan.

Dari awal kegiatan, kami sebagai pelaksana sudah memotivasi para guru bahwa dari hasil karya yang dibuat guru bisa dipraktekkan ketika mengajar dan dibuat penelitian yang akhirnya menjadi karya ilmiah. Tetapi hasil karya saat ini belum memuaskan dikarenakan kesibukan guru yang bersangkutan

\section{SIMPULAN}

Selama workshop bagi guru-guru matematika SMP Muhammadiyah se-Kabupaten Bantul yang berlangsung di PDM Bantul, para guru aktif mengikuti setiap sesinya dan terlihat sangat antusias. Para guru bersedia meluangkan waktu untuk mengikuti workshop ini karena materi yang diberikan sangat bermanfaat untuk pengembangan profesionalisme sebagai guru matematika di sekolah Muhammadiyah. Hasil angket yang diberikan guru, sebelum dan sesudah mengikuti workshop diketahui nilai rata-rata sebelum mengikuti workshop yaitu 33,28 pada kategori cukup serta nilai rata-rata sesudah mengikuti workshop yaitu 37,09 pada kategori baik.

Dengan melihat antusias para guru dan manfaat yang bisa diambil oleh para guru, maka kami pelaksana berencana akan melanjutkan pengabdian pada kegiatan pembimbingan sehingga guru-guru dapat menghasilkan karya ilmiah. Karya ilmiah ini dapat dibuat dari hasil penelitian guru tentang pembelajaran matematika yang menggunakan media yang sudah dibuat guru. Sehingga dari hasil karya ilmiah ini bisa dimanfaatkan oleh guru sendiri maupun sekolah.

Saran yang dapat direkomendasikan adalah peserta kegiatan hendaknya dapat meluangkan waktu lebih banyak dalam kegiatan pembimbingan/pendampingan agar proses pembuatan karya ilmiah bisa selesai., pemateri perlu memberikan contoh yang dapat ditiru/diedit oleh peserta dalam menyusun karya ilmiah, sekolah perlu memberi perhatian dan penghargaan kepada guru yang produktif dalam pembuatan karya ilmiah, dan PDM Bantul 
hendaknya menerapkan kebijakan untuk memberikan penghargaan pada guru yang produktif menyusun karya ilmiah agar guru semakin termotivasi meningkatkan kompetensi profesionalnya.

\section{UCAPAN TERIMAKASIH}

Tim pengabdian kepada masyarakat menyampaikan terima kasih kepada Lembaga Penelitian dan Pengabdian kepada Masyarakat (LPPM) Universitas Ahmad Dahlan yang telah mendanai, membina, dan memonitor kegiatan ini sehingga dapat berjalan lancar dan mencapai tujuan dengan baik.

\section{DAFTAR PUSTAKA}

Arifin, E.Z. (2003). Dasar-dasar Penulisan Karangan Ilmiah. Jakarta: Grasindo. Brotowidjoyo, M.D. (1985). Penulisan Karangan Ilmiah. Jakarta: Akademika Pressindo.

Effendi, A.S. (1987). Pedoman Penulisan Laporan Penelitian. Jakarta: Pusat Pembinaan dan Pengembangan Bahasa.

Sumardi. (2011). Meningkatkan Profesionalime Guru. Prosiding Seminar Karya Tulis Ilmiah di SD N Bantul. Bantul: SD N Bantul. 
